\title{
KEBUTUHAN AIR BERSIH MASYARAKAT DI KABUPATEN KEPULAUAN ANAMBAS
}

\author{
Communal Water Demand in Kabupaten Kepulauan Anambas \\ Oleh: \\ Taty Hernaningsih dan Satmoko Yudo \\ Pusat Teknologi Lingkungan, BPPT
}

\begin{abstract}
Abstrak
Kabupaten Kepulauan Anambas terdiri dari pulau-pulau kecil dengan daerah tangkapan air sangat minim, oleh karena itu ketersediaan air bersih untuk kebutuhan air masyarakat tidak dapat dipenuhi pada musim-musim tertentu. Masalah air di Kepulauan Anambas terutama di sumber-sumber mata air adalah penurunan debit mata air (krisis air) serta kerusakan pada Daerah Aliran Sungai (DAS). Hanya di Kecamatan Tarempa saja yang memiliki sistem pengolahan air, sedangkan penduduk yang berada pulau-pulau lain mendapatkan air dari mata air atau air permukaan melalui pipa yang dibangun secara individu maupun komunal tanpa dilakukan pengolahan air. Jumlah penduduk dan kegiatan masyarakat di Anambas meningkat sangat pesat sedangkan infrastruktur yang disediakan oleh pemerintah daerah belum memadai. Dalam mengantisipasi perkembangan ini diperlukan perencanaan kota yang baik, khususnya di bidang penyediaan air bersih bagi masyarakat di Kabupaten Kepulauan Anambas. Penentuan berapa besar kebutuhan air bersih masyarakat di Anambas, harus dihitung berdasarkan populasi dan permintaan air yang diproyeksikan per orang sesuai dengan standar yang ditetapkan DitJen Cipta Karya Kementerian Pekerjaan Umum. Metode yang digunakan dalam menghitung proyeksi kebutuhan air adalah dengan metode statistik (aritmatika, kuadrat terkecil, geometris, atau dengan menggunakan trend pertumbuhan penduduk dalam bentuk metode regresi). Proyeksi hasil kebutuhan air dari tahun 2013 sampai tahun 2032 yang telah dihitung adalah kecamatan-kecamatan Siantan, Siantan Tengah, Siantan Timur, Selatan Siantan, Palmatak, Jemaja, Jemaja Timur dan pulau-pulau kecil dengan ketersediaan air yang terbatas. Berdasarkan perhitungan proyeksi kebutuhan air penduduk, maka telah dilakukan perencanaan pemasangan instalasi pengolahan air bersih berikut kapasitas terpasangnya yang dilakukan secara bertahap dalam rangka memberikan pelayanan air bersih untuk semua penduduk di Kabupaten Kepulauan Anambas.
\end{abstract}

Kata kunci : Kebutuhan air bersih, metoda statistik, proyeksi, instalasi pengolahan air bersih dengan kapasitas terpasang.

\begin{abstract}
Kabupaten of Anambas Island consists of small islands with a catchment area is minimal; therefore the availability of clean water for public water needs cannot be available at certain seasons. Water problems in Anambas especially in spring sources is a decrease in discharge of springs (water crisis) as well as damage to the Watershed (DAS). Only in District Tarempa who have a water treatment system, while the population of the other islands to get water from springs or surface water through pipes that are built individually and communally without any water treatment. The population and activities of community in Anambas increased very rapidly while the infrastructure provided by the local government has not been adequate. In anticipation of these developments required a good city planning, particularly in the provision of clean water for people in Anambas Island. To determine how much water needs of the community in Anambas, should be calculated based on the population and projected water demand per person in accordance with standards established by Directorate General of Human Settlements Ministry of Public Works. The method used in calculating the projected water demand is the statistical method (arithmetic, least squares, geometric, or by using the trend of population growth in the form of regression method). Projected water demand results from the year 2013 to the year 2032 which has been calculated is Kecamatan Siantan, Central Siantan, Siantan East, South Siantan, Palmatak, Jemaja, East Jemaja and small islands with limited water availability. Based on the calculation of the projected water needs of the population, it has made planning the installation of water treatment plants following its installed capacity is achieved in stages in order to provide water services to all residents in Anambas Island.
\end{abstract}

Keywords : Water resources, statistic method, installed capacity. 


\section{PENDAHULUAN}

Kabupaten Kepulauan Anambas merupakan salah satu diantara daerah otonomi baru yang secara geografis merupakan gugusan pulau-pulau kecil yang terdiri dari 238 pulau dengan luas daratan 46.664,14 $\mathrm{Km}^{2}$ (1,38\% dari total luas wilayah) dikelilingi oleh lautan seluas $46.033,81 \mathrm{Km}^{2}(98,62 \%)$ dari total luas wilayah). Dengan Berkembangnya menjadi daerah otonomi telah membuka peluang yang sebesarbesarnya bagi Pemerintah Daerah untuk mempercepat pembangunan di semua sektor. Peta lokasi Kabupaten Kepulauan Anambas dapat dilihat pada Gambar 1 (Peta Administrasi Provinsi Kepulauan Riau, tahun 2006).

Kondisi geografis yang terdiri dari pulaupulau kecil menyebabkan daerah resapan/tangkapan air sangat minim, oleh karena itu ketersediaan air bersih untuk kebutuhan keseharian masyarakat tidak dapat terpenuhi pada musim-musim tertentu.

Mengingat kondisi permasalahan

sumberdaya air di Kabupaten Kepulauan Anambas terutama sumberdaya air baku seperti mata air adalah terjadinya penurunan debit mata air (krisis air) serta kerusakan Daerah Aliran Sungai (DAS). Ini dapat dilihat dari kondisi sumber mata air yang terdapat di Pulau Siantan, Pulau Matak, Pulau Jemaja, Pulau Mubur; dan Pulau Bajau debitnya sudah berkurang. Sesuai dengan UU No.7 Tahun 2004 tentang Sumber Daya Air, PP No.16 Tahun 2005, tentang Pengembangan SPAM maka pemerintah daerah harus melakukan pelestarian terhadap sumber air tersebut.

Penyediaan air minum melalui PDAM yang dibangun Direktorat Cipta Karya PU hanya terdapat di Kecamatan Tarempa sedangkan pulau-pulau lainnya sebagian besar jumlah penduduk mendapatkan air dari mata air ataupun air permukaan dengan melalui pipa yang dibangun secara individual atapun komunal tanpa pengolahan air (Pemerintah Kabupaten Kepulauan Anambas, 2000-2001). Sistem pengelolaan PDAM Tarempa dan distribusi air masih belum optimal, sehingga hanya sebagian kecil penduduk yang mendapat pelayanan air. Selain itu rendahnya kesadaran penduduk untuk menggunakan air dengan kualitas memenuhi baku mutu air bersih menyebabkan seringnya beberapa penduduk yang mengalami penyakit yang disebabkan oleh air seperti diare dan penyakit kulit .

Dilain pihak perkembangan penduduk dan aktivitas di Kabupaten Kepulauan Anambas meningkat sangat pesat sedangkan sarana dan prasarana yang disediakan pemerintah daerah belum memadai. Sehingga untuk mengatisipasi perkembangan ini diperlukan suatu perencanaan kota yang baik khususnya dalam bidang air minum. Salah satu yang terpenting dalam perencanaan ini adalah menentukan kebutuhan air bersih di Kabupaten Kepulauan Anambas.

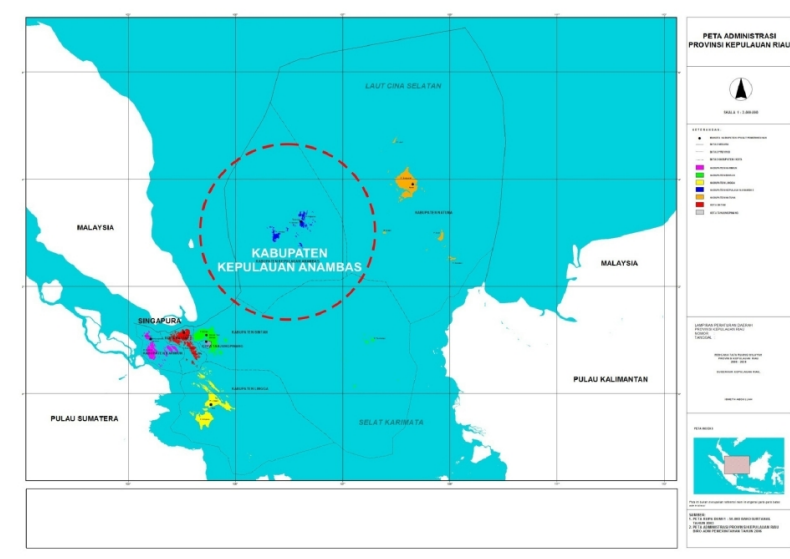

Gambar 1 : Peta Lokasi Kabupaten Kepulauan Anambas

\section{TUJUAN DAN SASARAN}

Tujuan kegiatan ini adalah melakukan proyeksi penduduk dan menentukan kebutuhan air bersih di Kabupaten Kepulauan Anambas.

\section{METODOLOGI}

1) Studi literature,

2) Interview dan kuesioner,

3) Perhitungan proyeksi dengan metoda Statistik

\subsection{Dasar Teori}

\section{a. Metoda Statistik}

Metoda statistik yang umum dipakai dalam perhitungan proyeksi penduduk adalah sebagai berikut (Anton Dayan, 1986):

- Metoda aritmatik

- Metoda geometrik,

- Metoda least square.

Atau dengan menggunakan trend pertumbuhan penduduk dalam bentuk metoda regresi, diantaranya:

- $\quad$ Regresi Linier

- Regresi Logaritma

- Regresi Eksponensial

- Regresi Power

b. Pengujian Metoda Terpilih

Pemilihan metoda proyeksi yang akan dipakai pada dasarnya dapat langsung ditetapkan berdasarkan gambaran yang dihasilkan dari data berkala yang disesuaikan dengan kriteria tiap-tiap metoda proyeksi. Selain itu pemilihan dapat juga dilakukan secara statistik. 
Ada dua cara pengujian statistik terhadap metoda terpilih, yaitu:

\section{- Standar deviasi}

Rumus standar deviasi:

$$
\begin{aligned}
& s=\left[\frac{\sum\left(\mathrm{X}-\mathrm{X}^{\prime}\right)^{2}}{\mathrm{n}}\right]^{0.5} \quad \text { untuk } \mathrm{n}>20 \\
& s=\left[\frac{\sum\left(\mathrm{X}-\mathrm{X}^{\prime}\right)^{2}}{\mathrm{n}-1}\right]^{0.5} \quad \text { untuk } \mathrm{n}<20
\end{aligned}
$$

dimana:

$\mathrm{s}=$ standar deviasi

$X=$ nilai hasil proyeksi

$X^{\prime}=$ nilai data awal

$\mathrm{n}=$ jumlah data

Metoda proyeksi yang baik adalah yang mempunyai nilai standar deviasi terkecil.

\section{- Koefisien korelasi}

Rumus koefisien korelasi adalah:

$$
r= \pm \sqrt{1-\left[\frac{\sum\left(\mathrm{X}-\mathrm{X}_{1}\right)^{2}}{\sum\left(\mathrm{X}-\mathrm{X}^{\prime}\right)^{2}}\right]}
$$

$$
\begin{array}{ll}
\text { dimana: } & \\
r & =\text { koefisien korelasi } \\
\mathrm{X} 1 & =\text { data awal } \\
\mathrm{X} & =\text { hasil proyeksi } \\
\mathrm{X}^{\prime} & =\text { rata-rata data awal. }
\end{array}
$$

Metoda yang terbaik adalah metoda yang mempunyai nilai $r$ mendekati 1 atau -1 .

Pendekatan lain yang dapat digunakan untuk melakukan prediksi jumlah penduduk adalah dengan mengamati kecenderungan perkembangan kawasan terkait. Untuk kawasan yang mempunyai prospek perkembangan yang dianggap tumbuh dengan cepat dengan indicator perencanaan wilayah, aktifitas perekonomian kawasan, dan kehidupan sehari-hari dikawasan itu, mempunyai kecenderungan laju pertumbuhan penduduk yang lebih tinggi dibandingkan dengan kawasan yang kecepatannya tumbuh lebih rendah. Oleh karena itu kurva proyeksi setiap kawasan, dalam hal ini di 5 kecamatan di Kabupaten Kepulauan Anambas mempunyai kemiringan lengkungan yang berbeda-beda.

\section{KEBUTUHAN AIR DI ANAMBAS}

\subsection{Rencana Daerah Pelayanan}

Secara garis besar, pelayanan air minum Kabupaten Anambas khususnya sistem perpipaan akan dilayani PDAM Kabupaten Anambas. Sedangkan untuk wilayah dengan sistem non perpipaan akan dilayani oleh Dinas Pekerjaan Umum yang membawahi BLU, Koperasi Air Minum, KM-PAM (Kelompok Masyarakat Pemakai Air Minum/LKMD).

Rencana Wilayah Pelayanan Air Minum Kabupaten Anambas dibagi atas:

a. Wilayah pelayanan PDAM Kabupaten Anambas

Ada 3 Kecamatan yang sudah dilayani PDAM yaitu Kecamatan Siantan, Kecamatan Palmatak dan Kecamatan Jemaja yang masing-masing secara berturut-turut terdiri 8 desa, 15 desa dan 9 desa. Tabel 1 (Lampiran) menunjukkan wilayah pelayanan PDAM Kabupaten Kepulauan Anambas.

b. Wilayah pelayanan non PDAM Kabupaten Anambas.

Pelayanan non PDAM belum ada di 4 Kecamatan yaitu Kecamatan Siantan Tengah, Siantan Timur, Siantan Selatan dan Jemaja Timur. Di keempat kecamatan tersebut terdapat 33 desa yang belum mendapat pelayanan PDAM. Tabel 2 (Lampiran) menunjukkan wilayah pelayanan non PDAM Kabupaten Kepulauan Anambas.

\subsection{Proyeksi Penduduk Anambas}

Perencanaan kebutuhan air minum untuk Kabupaten Anambas disusun dengan periode perencanaan selama 20 tahun mulai dari tahun 2013 sampai dengan. 2032 sehingga proyeksi penduduk dihitung sesuai dengan tahun perencanaan tersebut. (Droste, Ronald R. 1997).

\subsubsection{Hasil Proyeksi Penduduk}

Berdasarkan pengujian metoda seperti dijelaskan pada uraian sebelumnya, maka proyeksi penduduk untuk Kabupaten Anambas menurut kecamatan disajikan seperti pada Gambar 2 pada Lampiran.

Dari grafik pada Gambar 2 dapat dilihat bahwa untuk kecamatan dengan kegiatan ekonomi yang lebih tinggi, diproyeksikan mempunyai kecenderungan tumbuh dengan cepat, seperti Kecamatan Siantan dan Kecamatan Palmatak, sedangkan untuk kecamatan dengan aktifitas ekonomi yang relatif rendah, diproyeksikan tingkat pertambahan penduduk yang lebih rendah. 
Adapun realisasi pertambahan penduduk untuk setiap kecamatan dapat sewaktu-waktu dilakukan evaluasi dan perhitungan ulang setiap periode 5 tahun untuk akurasinya.

\subsection{Proyeksi Kebutuhan Air}

Proyeksi kebutuhan air minum dihitung berdasarkan jumlah penduduk dengan kebutuhan air sesuai dengan standar kriteria yang telah ditetapkan Ditjen Cipta Karya. Dasar perhitungan untuk kapasitas suatu sistem, tahapannya adalah:
1) Penentuan daerah pelayanan,
2) Proyeksi penduduk,
3) Jumlah penduduk yang dilayani,
4) Perbandingan Sambungan Rumah dan Hidran
Umum (Rasio SR : HU),
5) Penetapan konsumsi air,
6) Kehilangan air,
7) Faktor hari maksimum dan jam puncak

\subsubsection{Standar Kebutuhan Air}

Pemerintah Republik Indonesia melalui Direktorat Air Minum, Departemen Pekerjaan Umum telah menyusun program pelayanan air minum yang disesuaikan dengan kategori daerah. Kategori daerah tersebut dibuat berdasarkan jumlah penduduk. Pengelompokan tersebut dapat dilihat pada Tabel 3 (Ditjen. Cipta Karya, 1998).

Jika melihat jumlah penduduk di Kabupaten Kepulauan Anambas saat ini (BPS Kab. Kepulauan Anambas, 2010) dan proyeksi sampai akhir tahun perencanaan 2028, maka tingkat pelayanan kawasan ini termasuk kategori III dengan jumlah penduduk antara 100.000 s/d 500.000 jiwa.

Kebutuhan air domestik merupakan kebutuhan air bersih yang disampaikan pada tabel 3 digunakan untuk keperluan rumah tangga melalui sambungan kran ke rumah-rumah dan umum, yang jumlah kebutuhannya dapat dilihat dari catatan (data) dari kota atau daerah bersangkutan berdasarkan karakteristik dan perkembangan konsumen pemakai air bersih daerah tersebut.

Untuk kota kecil dan sedang konsumsi air untuk keperluan air non domestik (sosial, niaga, industri dll.) tidak seberapa besar namun pada kotakota besar kebutuhan air untuk keperluan ini dapat mencapai 30\% dari kebutuhan domestik

\subsubsection{Kebutuhan Air Penduduk}

Kebutuhan air bersih penduduk dihitung berdasarkan jumlah penduduk dan kebutuhan air per orang (Peraturan Menteri Pekerjaan Umum nomor
18/PRT/M/2007). Hasil perhitungan proyeksi kebutuhan air bersih di tiap kecamatan di Kabupaten Kepulauan Anambas disajikan pada Gambar 3 sampai dengan Gambar 9.

Tabel 3 : Kebutuhan Air minum Domestik.

\begin{tabular}{|c|c|c|c|c|c|}
\hline \multirow[t]{2}{*}{ No } & \multirow[t]{2}{*}{ Uraian } & \multicolumn{4}{|c|}{$\begin{array}{c}\text { Kategori Kota Berdasarkan Jumlah } \\
(\text { ( x 1000 Jiwa) }\end{array}$} \\
\hline & & $>1000$ & \begin{tabular}{|l|}
$500-$ \\
1000 \\
\end{tabular} & $100-500$ & $20-100$ \\
\hline \multirow{2}{*}{1.} & Konsumsi Unit SR & \multirow{2}{*}{200} & \multirow{2}{*}{150} & \multirow{2}{*}{125} & \multirow{2}{*}{100} \\
\hline & (Itr/org/hr) & & & & \\
\hline \multirow{2}{*}{2.} & Konsumsi Unit HU & \multirow{2}{*}{30} & \multirow{2}{*}{30} & \multirow{2}{*}{30} & \multirow{2}{*}{30} \\
\hline & (Ltr/org/hr) & & & & \\
\hline \multirow{2}{*}{3.} & Konsumsi non Domestik & \multirow{2}{*}{200} & \multirow{2}{*}{200} & \multirow{2}{*}{200} & \multirow{2}{*}{200} \\
\hline & (Itr/org/hr) & & & & \\
\hline 4. & Kehilangan (\%) & 25 & 25 & 25 & 25 \\
\hline 5. & Faktor harian Maksimum & 1,1 & 1,1 & 1,1 & 1,1 \\
\hline 6. & Faktor jam Maksimum & 1,5 & 1,5 & 1,5 & 1,5 \\
\hline 7. & Jumlah jiwa per SR & 6 & 6 & 5 & 5 \\
\hline 8. & \begin{tabular}{|l|} 
Sisa tekanan di jaringan \\
distr (mka)
\end{tabular} & $5-12,5$ & $5-12,5$ & $5-12,5$ & $5-12,5$ \\
\hline 9. & Jam operasi & 24 & 24 & 24 & 24 \\
\hline 10 & Cakupan pelayanan ( \%) & 80 & 80 & 80 & 80 \\
\hline \multicolumn{6}{|c|}{ Ditjen. Cipta Karya 1998} \\
\hline 1. & $\begin{array}{|lll|}\begin{array}{l}\text { Konsumsi } \\
\text { (Itr/org/hr) }\end{array} & \text { unit } & \text { SR } \\
\end{array}$ & 190 & 170 & 150 & 130 \\
\hline 2. & Kehilangan (\%) & $20-30$ & $20-30$ & $20--30$ & $20-30$ \\
\hline \multirow{2}{*}{3.} & Sisa tekanan di jaringan & \multirow{2}{*}{10} & \multirow{2}{*}{10} & \multirow{2}{*}{10} & \multirow{2}{*}{10} \\
\hline & distribusi ( $\mathrm{mka}$ ) & & & & \\
\hline 4. & Rasio SR : HU & $\begin{array}{c}50: 50 \\
s / d \\
80: 20\end{array}$ & $\begin{array}{c}50: 50 \\
s / d \\
80: 20\end{array}$ & $\begin{array}{c}80 \mathrm{~s} / \mathrm{d} \\
20\end{array}$ & $\begin{array}{c}50: 50 \\
-s / d \\
70: 30\end{array}$ \\
\hline
\end{tabular}

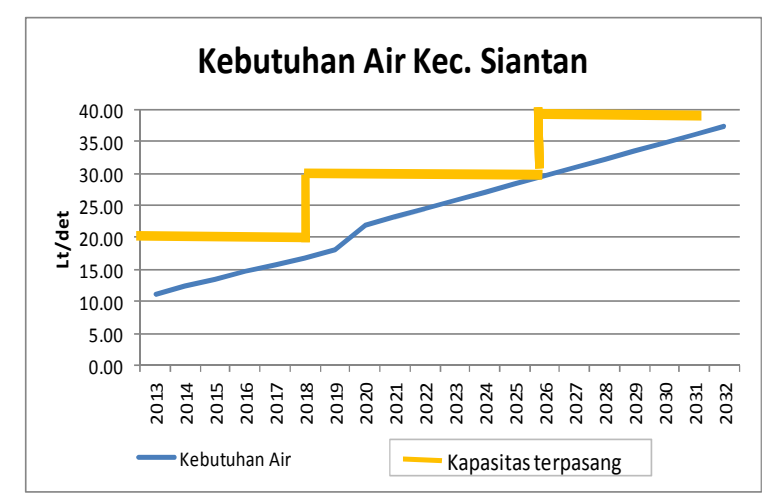

Gambar 3 : Proyeksi Kebutuhan Air di Kecamatan Siantan.

Dari gambar 3 dapat dilihat bahwa kapasitas terpasang di Kecamatan Siantan direncanakan akan meningkat dalam 3 tahap yaitu tahun 2013 sampai tahun 2018 sebesar 20 ltr/detik, tahun 2018 sampai tahun 2026 sebesar $20 \mathrm{ltr} /$ detik dan tahun 2026 sampai tahun 2032 sebesar 40 ltr/detik. 
Hal tersebut Telah disiapkan sejak tahun 2013 sampai tahun 2032. Dengan perencanaan 3 tahap kebutuhan air penduduk dapat dipenuhi sampai tahun 2032.

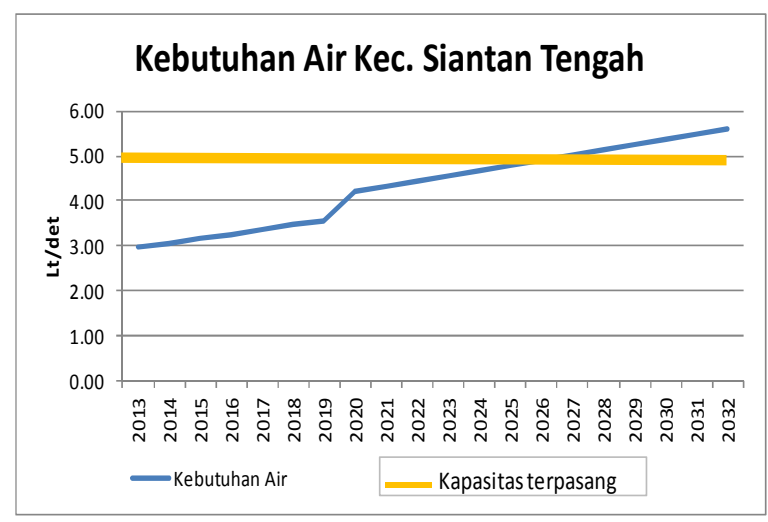

Gambar 4 : Proyeksi Kebutuhan Air di Kecamatan Siantan Tengah.

Dari Gambar 4 dapat dilihat bahwa kapasitas terpasang di Kecamatan Siantan Tengah direncanakan sebesar 5 liter/detik telah disiapkan sejak tahun 2013 sampai tahun 2032. Sedangkan kebutuhan airnya sampai tahun 2026 masih dibawah kapasitas terpasang. Kebutuhan air penduduk setelah tahun 2026 telah melebihi kapasitas terpasang berarti setelah tahun 2026 pelayanan air dibawah standar air minum yang telah ditetapkan kebutuhan air penduduk setelah tahun 2016 telah melebihi kapasitas terpasang berarti setelah tahun 2023 pelayanan air dibawah standar air minum yang telah ditetapkan.

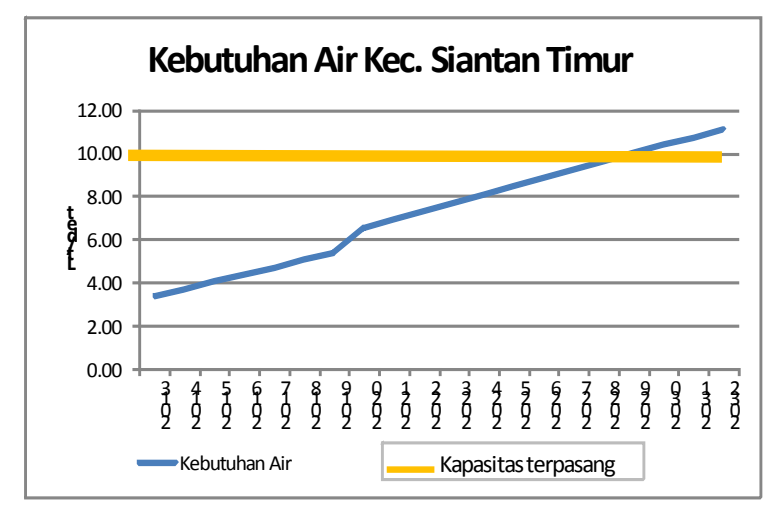

Gambar 5 : Proyeksi Kebutuhan Air di Kecamatan Siantan Timur.

Berdasarkan Gambar 5 telah disampaikan bahwa kapasitas terpasang di Siantan Timur sebesar 10 liter/detik direncanakan dapat memenuhi kebutuhan air penduduk sejak 2013 sampai tahun 2028. Setelah itu jumlah penduduk meningkat sehingga jumlah air yang diterima penduduknya berkurang dari standar yang ditentukan.

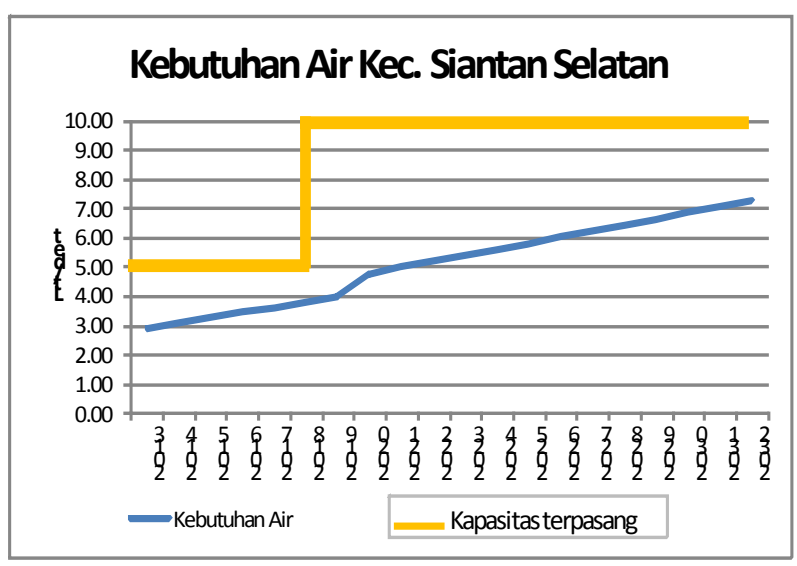

Gambar 6: Proyeksi Kebutuhan Air di Kecamatan Siantan Selatan.

Dari Gambar 6 dapat dilihat bahwa kapasitas terpasang Kecamatan Siantan Selatan direncanakan sebesar 5 Itr/detik dari tahun 2013 sampai tahun 2018. Kapasitas terpasang ditingkatkan menjadi 10 Itr/detik dari tahun 2018 sampai 2032 dan dari grafik dapat dilihat bahwa kebutuhan air di bawah kapasitas terpasang. Dengan kondisi ini maka penyediaan air masih dapat mencukupi kebutuhan penduduk sampai beberapa tahun mendatang.

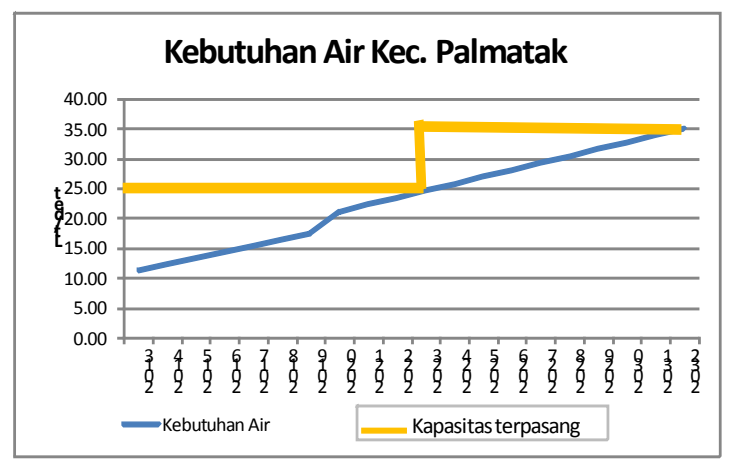

Gambar 7 : Proyeksi Kebutuhan Air di Kecamatan Palmatak.

Dari gambar 7 dapat dilihat bahwa kapasitas terpasang di Kecamatan Palmatak direncanakan sebesar $25 \mathrm{ltr} /$ detik dari tahun 2013 sampai tahun 2022. Dengan adanya pertambahan penduduk maka kapasitas terpasang ditingkatkan menjadi $35 \mathrm{Itr} /$ detik dari tahun 2022 sampai 2032. Jadi dengan peningkatan ini dapat dipenuhi kebutuhan air penduduk sampai tahun 2032.

Sesuai Gambar 8 perencanaan kapasitas terpasang di Kec, Jemaja diproyeksikan sebesar 10 Itr/detik dari tahun 2013 sampai tahun 2022. 
Peningkatan penduduk menyebabkan adanya pertambahan kebutuhan air sehingga kapasitas terpasang ditingkatkan menjadi 14 Itr/detik dari tahun 2022 sampai 2032. Proyeksi kebutuhan air penduduk dapat mencukupi kebutuhan air masyarakat sampai tahun 2032.

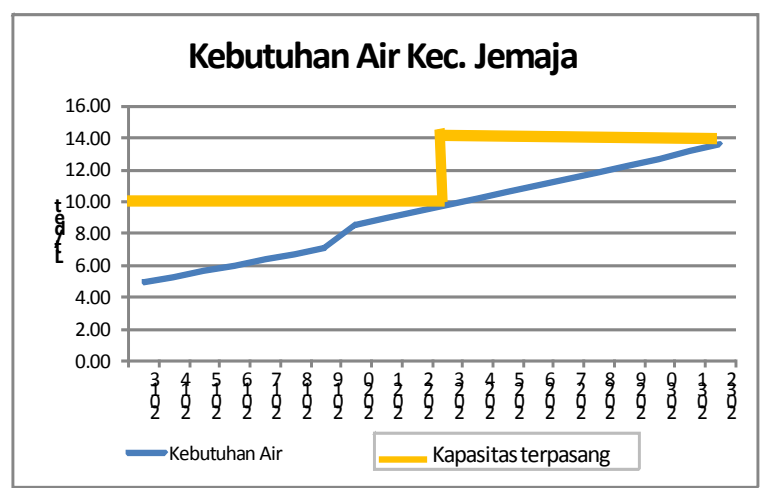

Gambar 8 : Proyeksi Kebutuhan Air di Kecamatan Jemaja.

Proyeksi kebutuhan air pada Gambar 9 menunjukkan kapasitas terpasang KecamatanJemaja Timur diproyeksikan sebesar 5 Itr/detik dari tahun 2013 sampai tahun 2032. Di lokasi ini, jumlah penduduk masih sedikit dan pertambahannya sangat kecil sehingga perencanaan penyediaan air akan dapat memenuhi sampai setelah tahun 2032.

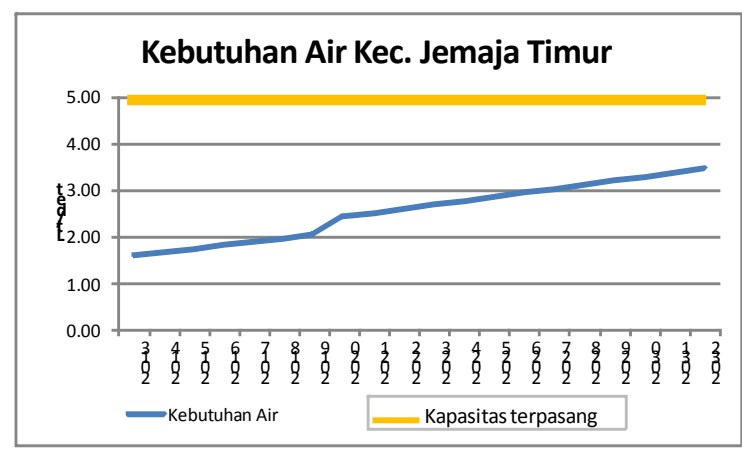

Gambar 9: Proyeksi Kebutuhan Air di Kecamatan Jemaja Timur

\subsubsection{Kebutuhan Air Minum Untuk Daerah Rawan Air}

Proyeksi penduduk di daerah rawan air dihitung sesuai dengan pertambahan penduduk kecamatan dengan hasil proyeksi dapat dilihat pada tabel 11 pada Lampiran. Jumlah penduduk yang paling tinggi di Desa Ladan, Kec. Palmatak dan yang paling rendah di Des Telaga Kecil, Kec. Siantan Selatan. Sedangkan kebutuhan air minum penduduk berdasarkan kebutuhan air per orang/hari dan hasil proyeksi penduduk dengan hasil perhitungan dapat dilihat pada tabel 12 pada Lampiran.

\section{KESIMPULAN DAN SARAN}

\subsection{Kesimpulan}

- Perencanaan kapasitas terpasang instalasi pengolahan air bersih dihitung berdasarkan kebutuhan air bersih penduduk dari tahun 2013 sampai 2032.

- Kebutuhan air bersih dihitung berdasarkan proyeksi penduduk dan kebutuhan air per orang sesuai dengan standar yang telah ditetapkan Ditjen. Cipta Karya PU.

- $\quad$ Proyeksi kebutuhan air penduduk telah dihitung di 7 kecamatan yaitu: Siantan, Siantan Tengah, Siantan Timur, Siantan Selatan, Palamatak, Jemaja, Jemaja Timur dan daerah yang rawan air.

- Kapasitas terpasang dari masing-masing kecamatan telah dihitung untuk memenuhi kebutuhan air penduduk yang direncanakan ada yang dilakukan secara bertahap agar lebih ekonomis dan semua penduduk dilokasi tersebut mendapat pelayanan air bersih yang cukup.

\subsection{Saran}

- Pengumpulan data penduduk sebagai dasar perencanaan sebaiknya 10 tahun berturut-turut.

- Penentuan metoda harus mempertimbangkan hasil penggunaan metoda yang mempunyai nilai standar deviasi terkecil.

- Perhitungan kapasitas terpasang harus dapat melayani kebutuhan air sesuai dengan standar sampai akhir tahun perencanaan.

\section{DAFTAR PUSTAKA}

- Ditjen. Cipta Karya 1998, Kebutuhan Air minum Domestik.

- BPS Kab. Kepulauan Anambas, Kepulauan Anambas Berdasarkan Angka, 2010.

- Peta Administrasi Provinsi Kepulauan Riau, Biro Administrasi Pemerintah, tahun 2006.

- Pemerintah Kabupaten Kepulauan Anambas, Rencana Tata Ruang Wilayah Kabupaten Kepulauan Anambas, Propinsi Kepulauan Riau, 2000-2001.

- $\quad$ Anton Dayan, Pengantar Metode Statistik J ¡ilid H, LP3S, Jakarta, 1986. 
- Peraturan Menteri Pekerjaan Umum nomor 18/PRT/M/2007 tentang Penyelenggaraan Pengembangan Sistem Penyediaan Air Minum
- $\quad$ Droste, Ronald R. (1997). Theory and Practice of Water and Wastewater Treatment. John wiley and Sons Ltd.Toroto, Canada. 


\section{LAMPIRAN}

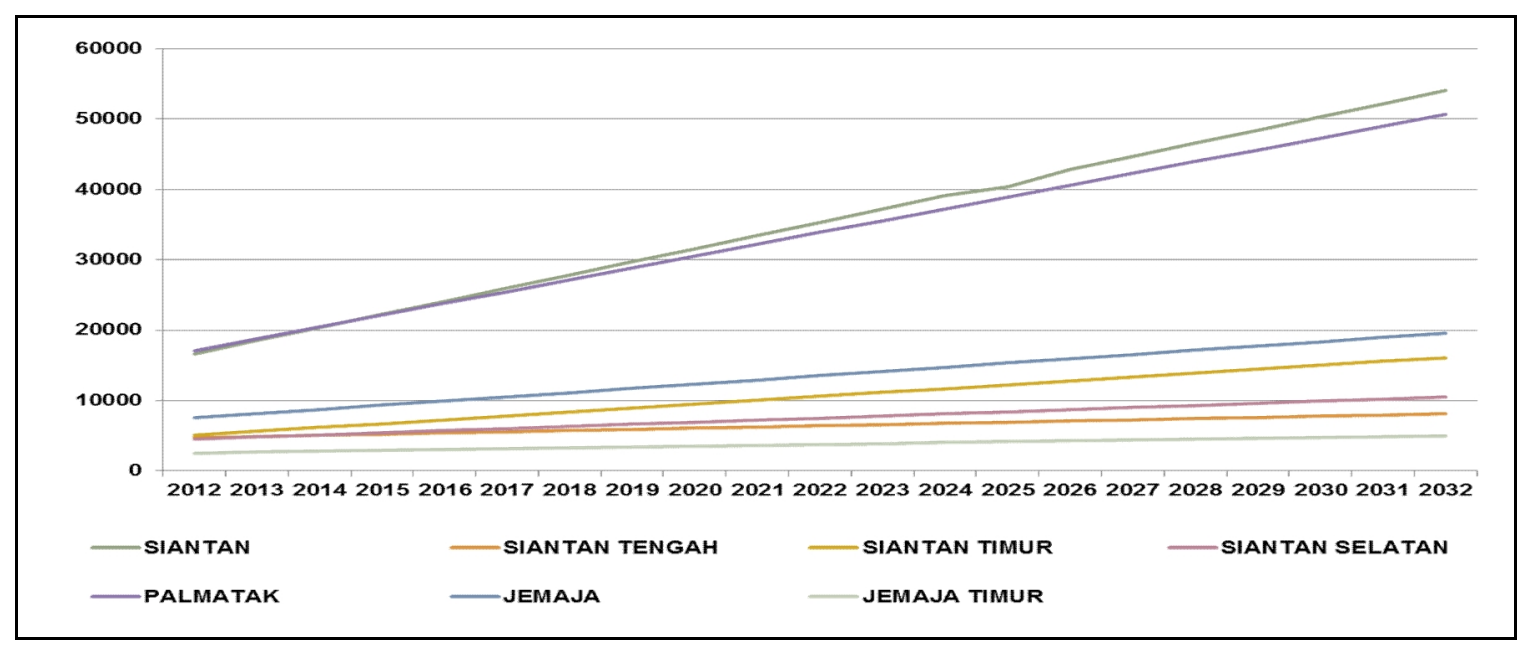

Gambar 2 : Grafik Proyeksi Pertambahan Penduduk Di Kabupaten Kepulauan Anambas.

Tabel 1 : Wilayah Pelayanan PDAM Kabupaten Kepulauan Anambas.

\begin{tabular}{|c|c|c|c|}
\hline \multicolumn{4}{|c|}{ WILAYAH PELAYANAN PDAM KAB.ANAMBAS } \\
\hline No & KECAMATAN & IKK & DESA \\
\hline \multirow[t]{7}{*}{1} & Siantan & Tarempa & 1. Kel. Tarempa \\
\hline & & & 2. Tarempa Barat \\
\hline & & & 3.Tarempa Timur \\
\hline & & & 4. Tarempa Selatan \\
\hline & & & 5. Pesisir Timur. \\
\hline & & & 6. Tarempa Barat Daya \\
\hline & & & $\begin{array}{l}\text { 7. Sri Tanjung / } \\
\text { T.Lambai }\end{array}$ \\
\hline \multirow[t]{15}{*}{2} & Palmatak & T.Ladan & 1. Tebang. \\
\hline & & & 2. Ladan. \\
\hline & & & 3. Mubur. \\
\hline & & & 4. Putik. \\
\hline & & & 5. Payalaman. \\
\hline & & & 6. Bayat. \\
\hline & & & 7. Piabung \\
\hline & & & 8 Langir. \\
\hline & & & 9. Candi. \\
\hline & & & 10. Piasan. \\
\hline & & & 11. Batu Ampar. \\
\hline & & & 12. Teluk Bayur/ Durian \\
\hline & & & 13. Belibak. \\
\hline & & & 14. Matak Kecil. \\
\hline & & & 15. Payamaran. \\
\hline \multirow[t]{9}{*}{3} & Jemaja & Letung & 1. Kel. Letung. \\
\hline & & & 2. Keramut. \\
\hline & & & 3. Rewak. \\
\hline & & & 4. Impol \\
\hline & & & 5. Sunggak. \\
\hline & & & 6. Mampok. \\
\hline & & & 7. Air Biru. \\
\hline & & & 8. Batu Berapit. \\
\hline & & & 9. Landak \\
\hline
\end{tabular}


Tabel 2 : Wilayah Pelayanan Non PDAM Kabupaten Kepulauan Anambas.

\begin{tabular}{|c|c|c|c|}
\hline \multicolumn{4}{|c|}{ WILAYAH PELAYANAN NON PDAM } \\
\hline No & KECAMATAN & IKK & DESA \\
\hline 1 & $\begin{array}{l}\text { SIANTAN } \\
\text { TENGAH }\end{array}$ & AIR ASUK & 1. Tekuk Siantan \\
\hline & & & 2. Air Asuk \\
\hline & & & 3. Air Sena. \\
\hline & & & 4. Lidi. \\
\hline & & & 5. Teluk Sunting \\
\hline & & & 6. Liuk \\
\hline 2 & $\begin{array}{l}\text { SIANTAN } \\
\text { TIMUR }\end{array}$ & NYAMUK & 1. Batu Belah \\
\hline & & & 2. Nyamuk. \\
\hline & & & 3. Munjan. \\
\hline & & & 4. Temburun. \\
\hline & & & 5. Serat. \\
\hline & & & 6. Air Putih. \\
\hline 3 & $\begin{array}{l}\text { SIANTAN } \\
\text { SELATAN }\end{array}$ & AIR BINI & 1. Tiangau \\
\hline & & & 2. Lingai. \\
\hline & & & 3.Kiabu. \\
\hline & & & 4. Telaga. \\
\hline & & & 5. Telaga Kecil. \\
\hline & & & 6. Mengkait. \\
\hline & & & 7. Air Bini. \\
\hline 4 & JEMAJA TIMUR & $\begin{array}{l}\text { KUALA } \\
\text { MARAS }\end{array}$ & 1. Ulu Maras \\
\hline & & & 2. Bukit Padi. \\
\hline & & & 3. Kuala Maras. \\
\hline & & & 4. Genting Pulur. \\
\hline
\end{tabular}

Tabel 4 : Proyeksi Penduduk Daerah Rawan.

\begin{tabular}{|c|c|c|c|c|c|c|c|c|c|c|c|c|c|c|}
\hline$\overline{\text { TAHUN }}$ & $\begin{array}{l}\text { SRI TANJUNG/ } \\
\text { T LAMBAI(jiwa) }\end{array}$ & $\begin{array}{l}\text { LIDI } \\
\text { (jiwa) }\end{array}$ & $\begin{array}{l}\text { LIUK } \\
\text { (jiwa) }\end{array}$ & $\begin{array}{c}\text { T SUNTING } \\
\text { (jiwa) }\end{array}$ & $\begin{array}{l}\text { MUNJAN } \\
\text { (jiwa) }\end{array}$ & $\begin{array}{l}\text { LINGAI } \\
\text { (jiwa) }\end{array}$ & $\begin{array}{l}\text { TELAGA K } \\
\text { (jiwa) }\end{array}$ & $\begin{array}{l}\text { MENGKAIT } \\
\text { (jiwa) }\end{array}$ & $\begin{array}{c}\text { TEBANG } \\
\text { (jiwa) }\end{array}$ & $\begin{array}{l}\text { LADAN } \\
\text { (jiwa) }\end{array}$ & $\begin{array}{c}\text { PUTIK } \\
\text { (jiwa) }\end{array}$ & $\begin{array}{c}\text { BELIBAK } \\
\text { (jiwa) }\end{array}$ & $\begin{array}{l}\text { REWAK } \\
\text { (jiwa) }\end{array}$ & $\begin{array}{l}\text { IMPOL } \\
\text { (jiwa) }\end{array}$ \\
\hline 2.013 & 666 & 341 & 380 & 600 & 935 & 355 & 249 & 1.015 & 1.521 & 2.055 & 1.769 & 407 & 759 & 369 \\
\hline 2.014 & 729 & 354 & 395 & 623 & 1.011 & 375 & 263 & 1.072 & 1.645 & 2.222 & 1.914 & 440 & 772 & 375 \\
\hline 2.015 & 797 & 368 & 410 & 648 & 1.093 & 396 & 278 & 1.133 & 1.780 & 2.404 & 2.070 & 476 & 784 & 381 \\
\hline 2.016 & 873 & 382 & 426 & 673 & 1.182 & 419 & 294 & 1.197 & 1.925 & 2.600 & 2.239 & 515 & 797 & 387 \\
\hline 2.017 & 955 & 397 & 442 & 699 & 1.279 & 442 & 310 & 1.264 & 2.082 & 2.812 & 2.422 & 557 & 810 & 394 \\
\hline 2.018 & 1.045 & 413 & 460 & 726 & 1.383 & 467 & 328 & 1.336 & 2.252 & 3.042 & 2.619 & 603 & 824 & 400 \\
\hline 2.019 & 1.143 & 429 & 478 & 754 & 1.496 & 494 & 346 & 1.411 & 2.436 & 3.291 & 2.833 & 652 & 837 & 407 \\
\hline 2.020 & 1.251 & 445 & 496 & 784 & 1.618 & 522 & 366 & 1.491 & 2.635 & 3.559 & 3.065 & 705 & 851 & 413 \\
\hline 2.021 & 1.369 & 463 & 515 & 814 & 1.750 & 551 & 387 & 1.575 & 2.850 & 3.850 & 3.315 & 763 & 865 & 420 \\
\hline 2.022 & 1.499 & 481 & 535 & 846 & 1.892 & 582 & 408 & 1.665 & 3.083 & 4.164 & 3.586 & 825 & 879 & 427 \\
\hline 2.023 & 1.640 & 499 & 556 & 879 & 2.047 & 615 & 431 & 1.759 & 3.335 & 4.505 & 3.879 & 893 & 893 & 434 \\
\hline 2.024 & 1.795 & 519 & 578 & 913 & 2.214 & 650 & 456 & 1.858 & 3.607 & 4.872 & 4.195 & 966 & 908 & 441 \\
\hline 2.025 & 1.964 & 539 & 600 & 948 & 2.394 & 687 & 482 & 1.963 & 3.902 & 5.270 & 4.538 & 1.044 & 923 & 448 \\
\hline 2.026 & 2.149 & 560 & 624 & 985 & 2.589 & 726 & 509 & 2.074 & 4.220 & 5.701 & 4.909 & 1.130 & 938 & 456 \\
\hline 2.027 & 2.352 & 582 & 648 & 1.023 & 2.800 & 767 & 538 & 2.191 & 4.565 & 6.166 & 5.309 & 1.222 & 953 & 463 \\
\hline 2.028 & 2.574 & 604 & 673 & 1.063 & 3.029 & 810 & 568 & 2.315 & 4.938 & 6.670 & 5.743 & 1.322 & 969 & 471 \\
\hline 2.029 & 2.816 & 628 & 699 & 1.104 & 3.276 & 856 & 600 & 2.446 & 5.341 & 7.215 & 6.212 & 1.430 & 985 & 478 \\
\hline 2.030 & 3.082 & 652 & 726 & 1.147 & 3.543 & 904 & 634 & 2.585 & 5.777 & 7.804 & 6.719 & 1.547 & 1.001 & 486 \\
\hline 2.031 & 3.373 & 677 & 755 & 1.192 & 3.832 & 955 & 670 & 2.731 & 6.249 & 8.441 & 7.268 & 1.673 & 1.017 & 494 \\
\hline 2.032 & 3.691 & 704 & 784 & 1.238 & 4.144 & 1.009 & 708 & 2.885 & 6.759 & 9.130 & 7.862 & 1.809 & 1.034 & 502 \\
\hline
\end{tabular}


Tabel 5 : Kebutuhan Air Minum Untuk Daerah Rawan Air.

\begin{tabular}{|c|c|c|c|c|c|c|c|c|c|c|c|c|c|c|}
\hline $\begin{array}{r}\text { TAHUN } \\
T\end{array}$ & $\begin{array}{l}\text { SRI TANJUNG/ } \\
\text { T LAMBAI }(\mathrm{m} 3 / \mathrm{h}\end{array}$ & $\begin{array}{c}\text { LIDI } \\
\text { (m3/hr) }\end{array}$ & \begin{tabular}{|c|} 
LIUK \\
$(\mathrm{m} 3 / \mathrm{hr})$
\end{tabular} & $\begin{array}{l}\text { SUNTIN } \\
\text { (m3/hr) }\end{array}$ & $\begin{array}{l}\text { MUNJAN } \\
(\mathrm{m} 3 / \mathrm{hr})\end{array}$ & $\begin{array}{l}\text { LINGAI } \\
\text { (m3/hr) }\end{array}$ & \begin{tabular}{|c|} 
TELAGA K \\
$(\mathrm{m} 3 / \mathrm{hr})$
\end{tabular} & $\begin{array}{l}\text { MENGKAIT } \\
(\mathrm{m} 3 / \mathrm{hr})\end{array}$ & \begin{tabular}{|c|} 
TEBANG \\
$(\mathrm{m} 3 / \mathrm{hr})$
\end{tabular} & $\begin{array}{l}\text { LADAN } \\
(\mathrm{m} 3 / \mathrm{hr})\end{array}$ & \begin{tabular}{|l|} 
PUTIK \\
$(\mathrm{m} 3 / \mathrm{hr})$
\end{tabular} & $\begin{array}{c}\text { BELIBAK } \\
(\mathrm{m} 3 / \mathrm{hr})\end{array}$ & $\begin{array}{l}\text { REWAK } \\
\text { (m3/hr) }\end{array}$ & \begin{tabular}{|l|} 
IMPOL \\
(m3/hr)
\end{tabular} \\
\hline 2013 & 3,3 & 1,7 & 1,9 & 3,0 & 4,7 & 1,8 & 1,2 & 5,1 & \begin{tabular}{|l|}
7,6 \\
\end{tabular} & 10,3 & 8,8 & 2,0 & 3,8 & 1,8 \\
\hline 2014 & 3,6 & 1,8 & 2,0 & 3,1 & 5,1 & 1,9 & 1,3 & 5,4 & 8,2 & 11,1 & 9,6 & 2,2 & 3,9 & 1,9 \\
\hline 2015 & 4,0 & 1,8 & 2,0 & 3,2 & 5,5 & 2,0 & 1,4 & 5,7 & 8,9 & 12,0 & 10,3 & 2,4 & 3,9 & 1,9 \\
\hline 2016 & 4,4 & 1,9 & 2,1 & 3,4 & 5,9 & 2,1 & 1,5 & 6,0 & 9,6 & 13,0 & 11,2 & 2,6 & 4,0 & 1,9 \\
\hline 2017 & 4,8 & 2,0 & 2,2 & 3,5 & 6,4 & 2,2 & 1,6 & 6,3 & 10,4 & 14,1 & 12,1 & 2,8 & 4,1 & 2,0 \\
\hline 2018 & 5,2 & 2,1 & 2,3 & 3,6 & 6,9 & 2,3 & 1,6 & 6,7 & 11,3 & 15,2 & 13,1 & 3,0 & 4,1 & 2,0 \\
\hline 2019 & 5,7 & 2,1 & 2,4 & 3,8 & 7,5 & 2,5 & 1,7 & 7,1 & 12,2 & 16,5 & 14,2 & 3,3 & 4,2 & 2,0 \\
\hline 2020 & 6,3 & 2,2 & 2,5 & 3,9 & 8,1 & 2,6 & 1,8 & 7,5 & 13,2 & 17,8 & 15,3 & 3,5 & 4,3 & 2,1 \\
\hline 2021 & 6,8 & 2,3 & 2,6 & 4,1 & 8,7 & 2,8 & 1,9 & 7,9 & 14,3 & 19,2 & 16,6 & 3,8 & 4,3 & 2,1 \\
\hline 2022 & 7,5 & 2,4 & 2,7 & 4,2 & 9,5 & 2,9 & 2,0 & 8,3 & 15,4 & 20,8 & 17,9 & 4,1 & 4,4 & 2,1 \\
\hline 2023 & 8,2 & 2,5 & 2,8 & 4,4 & 10,2 & 3,1 & 2,2 & 8,8 & 16,7 & 22,5 & 19,4 & 4,5 & 4,5 & 2,2 \\
\hline 2024 & 9,0 & 2,6 & 2,9 & 4,6 & 11,1 & 3,3 & 2,3 & 9,3 & 18,0 & 24,4 & 21,0 & 4,8 & 4,5 & 2,2 \\
\hline 2025 & 9,8 & 2,7 & 3,0 & 4,7 & 12,0 & 3,4 & 2,4 & 9,8 & 19,5 & 26,4 & 22,7 & 5,2 & 4,6 & 2,2 \\
\hline 2026 & 10,7 & 2,8 & 3,1 & 4,9 & 12,9 & 3,6 & 2,5 & 10,4 & 21,1 & 28,5 & 24,5 & 5,6 & 4,7 & 2,3 \\
\hline 2027 & 11,8 & 2,9 & 3,2 & 5,1 & 14,0 & 3,8 & 2,7 & 11,0 & 22,8 & 30,8 & 26,5 & 6,1 & 4,8 & 2,3 \\
\hline 2028 & 12,9 & 3,0 & 3,4 & 5,3 & 15,1 & 4,0 & 2,8 & 11,6 & 24,7 & 33,3 & 28,7 & 6,6 & 4,8 & 2,4 \\
\hline 2029 & 14,1 & 3,1 & 3,5 & 5,5 & 16,4 & 4,3 & 3,0 & 12,2 & 26,7 & 36,1 & 31,1 & 7,1 & 4,9 & 2,4 \\
\hline 2030 & 15,4 & 3,3 & 3,6 & 5,7 & 17,7 & 4,5 & 3,2 & 12,9 & 28,9 & 39,0 & 33,6 & 7,7 & 5,0 & 2,4 \\
\hline 2031 & 16,9 & 3,4 & 3,8 & 6,0 & 19,2 & 4,8 & 3,3 & 13,7 & 31,2 & 42,2 & 36,3 & 8,4 & 5,1 & 2,5 \\
\hline 2032 & 18,5 & 3,5 & 3,9 & 6,2 & 20,7 & 5,0 & 3,5 & 14,4 & 33,8 & 45,7 & 39,3 & 9,0 & 5,2 & 2,5 \\
\hline
\end{tabular}

*Kebutuhan air: 30 Itr/jiwa/hari 